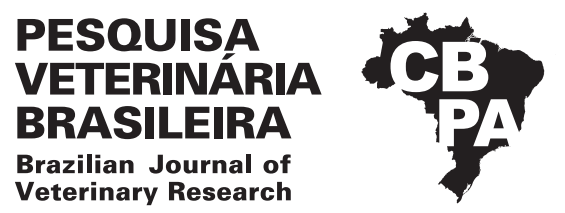

Pesq. Vet. Bras. 38(7):1444-1448, julho 2018 DOI: $10.1590 / 1678-5150-P V B-5700$

Original Article

Animais Selvagens/Wildlife Medicine

ISSN 0100-736X (Print)

ISSN 1678-5150 (Online)

\title{
Sarcoptic mange (Sarcoptes scabiei) in wild canids (Cerdocyon thous) $^{1}$
}

\author{
Tamires G.W. Teodoro², Pâmela A. Lima³ ${ }^{3}$ Patrícia C. Stehling ${ }^{4}$, Ivam M. Oliveira Junior², \\ Mary S. Varaschin ${ }^{2}$, Flademir Wouters ${ }^{2}$ and Angelica T.B. Wouters ${ }^{2 *}$
}

\begin{abstract}
Teodoro T.G.W., Lima P.A., Stehling P.C., Oliveira Junior I.M., Varaschin M.S., Wouters F. \& Wouters A.T.B. 2018. Sarcoptic mange (Sarcoptes scabiei) in wild canids (Cerdocyon thous). Pesquisa Veterinária Brasileira 38(7):1444-1448. Setor de Patologia Veterinária, Departamento de Medicina Veterinária, Universidade Federal de Lavras, Campus Universitário, Cx. Postal 3037, Lavras, MG 37200-000, Brazil. E-mail: angelica.wouters@dmv.ufla.br

Crab-eating foxes (Cerdocyon thous) are wild canids found in practically all Brazilian states. They usually live and hunt in pairs, but can be found in small groups, which favors the transmission of diseases such as sarcoptic mange. This study aims to describe the epidemiological, parasitological and pathological findings of two fatal cases of sarcoptic mange in $C$. thous. Two wild canids were necropsied and cytological examination of skin and crust samples and histologic evaluation of various tissue samples were performed. Gross findings included poor body condition and extensive alopecia with thick skin crusts interspersed by intensely reddened alopecic areas. The cytological examination revealed numerous mites with short gnathosoma and rounded idiosoma that were transversally striated and presented triangular spines on the dorsal surface, terminal anus, and short and thick legs, characteristic of Sarcoptes scabiei. Histologic examination of the skin revealed numerous tunnels into and under the stratum corneum of the epidermis containing high amounts of S. scabiei. The mites were associated with marked acanthosis and hyperkeratosis, and mild superficial dermatitis. The findings reveal that sarcoptic mange is an important disease in wild canids.
\end{abstract}

INDEX TERMS: Sarcoptic mange, Sarcoptes scabiei, Cerdocyon thous, wild canids, skin diseases, mites, scabies, parasitoses.

\begin{abstract}
RESUMO.-[Sarna sarcóptica (Sarcoptes scabiei) em cachorro-do-mato (Cerdocyon thous).] Cachorros-do-mato (Cerdocyon thous) são canídeos selvagens encontrados em praticamente todos os estados brasileiros. Geralmente vivem e caçam em pares, mas podem ser encontrados em pequenos grupos, o que favorece a transmissão de doenças, como a sarna sarcóptica. 0 presente trabalho tem como objetivo descrever os achados epidemiológicos, parasitológicos e patológicos de dois casos fatais de sarna sarcóptica em cachorros-do-mato. Foram realizados necropsia de dois cachorros do mato,
\end{abstract}

\footnotetext{
${ }^{1}$ Received on February 22, 2018.

Accepted for publication on March 1, 2018.

${ }^{2}$ Setor de Patologia Veterinária, Departamento de Medicina Veterinária, Universidade Federal de Lavras (UFLA), Campus Universitário, Cx. Postal 3037, Lavras, MG 37200-000, Brazil. *Corresponding author: angelica.wouters@dmv.ufla.br

${ }^{3}$ Escola de Veterinária, Universidade Federal de Minas Gerais, Campus Pampulha, Av. Antônio Carlos 6627, Belo Horizonte, MG 31270-901, Brazil.

${ }^{4}$ Médica Veterinária, Late Mia Pet Center, Av. Coronel Porfírio Ribeiro de Andrade 365, Pouso Alegre, MG 37550-000, Brazil.
}

exame citológico de amostras de pele e crostas e exame histológico de amostras dos órgãos e tecidos. Na necropsia foram observados mau estado corporal, extensas áreas de alopecia, crostas cutâneas espessas que se desprendiam e eram intercaladas por áreas alopécicas intensamente eritematosas. No exame citológico foi observada grande quantidade de ácaros com gnatossoma curto e largo, idiossoma globoso, transversalmente estriado e com espinhos triangulares na superfície dorsal, ânus terminal e pernas curtas e grossas, característicos de Sarcoptes scabiei. Ao exame histológico da pele havia muitos túneis no estrato córneo da epiderme e abaixo dele, contendo grande quantidade de S. scabiei. Essas estruturas parasitárias estavam associadas a acantose e hiperqueratose acentuadas e dermatite superficial discreta. Os achados revelam a sarna sarcóptica como uma doença importante em cachorros do mato.

TERMOS DE INDEXAÇÃO: Sarna sarcóptica, Sarcoptes scabiei, cachorro-do-mato, Cerdocyon thous, canídeos selvagens, doenças de pele, ácaros, escabiose, parasitoses. 


\section{INTRODUCTION}

Crab-eating Fox (Cerdocyon thous) is a medium-sized wild canid characterized by a grayish coat, which is darker in the medial region of the dorsum, scapula and limbs. This canid is found in practically all Brazilian states, inhabiting areas of forested and open environments such as the Cerrado. Wild canids usually live and hunt in pairs, but can also be found in small groups and present nighttime habits (Trovati etal. 2007, Di Bitetti etal. 2009, Faria-Corrêa et al. 2009, Jorge \& Jorge 2014).

Sarcoptic mange, or scabies, is a cutaneous disease caused by scavenger mites of the species Sarcoptes scabiei (Linneaus, 1758), family Sarcoptidae, that are highly contagious and may be airborne or transmitted by direct contact (Curtis 2004). Transmission tends to be dependent on animal density (Pence \& Ueckermann 2002). Several species of domestic and wild mammals can be parasitized (Arlian 1989, Monteiro 2010), with the disease described in 104 animal species (Pence \& Ueckermann 2002) as well as in humans (Larsson 1978). In North America, parasitism is described in epizootic outbreaks in wild canids, such as coyotes, red foxes, and gray wolves (Pence et al. 1983, Little et al. 1998, Jimenez et al. 2010).

S. scabiei adult females burrow tunnels or galleries in the skin (Serra-Freire 2001, Monteiro 2010), where they lay their eggs (Burkhart et al. 2000, Jimenez et at. 2010). Larvae, which undergo two nymphal stages (Jimenez et al. 2010), protonympha and trichonympha (Arlian \& Vyszenski-Moher 1988, Arlian 1989), hatch from these eggs. The cycle is complete in approximately two weeks, when the last nymph stage change to adult (Sweatman 1971, Arlian 1989, Serra-Freire 2001). Only approximately $10 \%$ of the eggs produced originate mites that reach mature age (Orion et al. 2006). All stages of S. scabiei can be found in the same host (Pence \& Ueckermann 2002), and all of them can form a system of tunnels or galleries in the epidermis; however, these tunnels are concluded by the adult females (Burkhart et al. 2000). Excavations on the skin, especially those made by adult females, induce thickening of the epidermis and crust formation (Pence \& Ueckermann 2002, Monteiro 2010).

Transmission between different hosts occurs when larvae, nymphs, or adult females are found on the skin (Burkhart et al. 2000, Serra-Freire 2001, Pence \& Ueckermann 2002). Specimens of Sarcoptes sp. found on different hosts may be difficult to distinguish (Fain 1968). The main morphological differences observed in this mite are related to size, body characteristics, and number of keratinized triangular spines found on the back of females (Arlian 1989). Mites persist in the environment for long periods, but survival depends on the environmental conditions and substrates (Arlian \& Vyszenski-Moher 1988), age of the host, temperature, and humidity (Pence et al. 1983).

The clinical signs most often observed in animals with acute sarcoptic mange are intense pruritus, erythematous eruptions, alopecia, and seborrhea (Burkhart et al. 2000). Skin changes range from small erythematous and alopecic areas with intense pruritus to more extensive lesions with severe hair loss, seborrhea, and hyperkeratosis (Rentería-Solís et al. 2014). Moderate-to-thick crusted plaques, with or without alopecia, and areas with scarce or absent hair and even without crusts have been described in wild canid populations (Pence et al. 1983). Hypersensitivity reactions, with reduction in the number of mites on the skin but with worsened skin lesions (Pence \& Ueckermann 2002), as described in foxes (Little et al. 1998), may occur. In a study conducted with coyotes in Texas, Pence et al. (1983) classified scabies lesions as focal, progressive (covering half of the body surface, on average), and total (covering the entire body surface).

This study aims to describe the epidemiological, parasitological, macroscopic, and histological findings of two fatal cases of sarcoptic mange in crab-eating foxes (Cerdocyon thous) and demonstrate the importance of the disease for this canid species.

\section{MATERIALS AND METHODS}

Two crab-eating foxes were taken to the Department of Veterinary Pathology of the Federal University of Lavras (SPV-DMV-UFLA), Lavras, Minas Gerais state, for necropsy. Samples of tissues and organs were collected, fixed in $10 \%$ buffered formalin, routinely processed for histology, embedded in paraffin, cut into $5 \mu \mathrm{m}$, and stained with hematoxylin and eosin (HE) for assessment by optical microscopy. Samples of skin with lesions, including crusts, were also collected for cytological evaluation. To this purpose, the samples were placed on glass slides, macerated and clarified with one or two drops of $10 \%$ potassium hydroxide for 5 to 10 minutes (Pence \& Ueckermann 2002, Taylor et al. 2010).

\section{RESULTS}

Of the two specimens of Cerdocyon thous examined, the first (Ct1, male, adult) was found dead in August 2006 and was referred by agents of the Military Environmental Police of Minas Gerais for necropsy, whereas the second (Ct2, female, adult) was found in serious condition in August 2014 and sent to the Veterinary Hospital of UFLA. Both wild canids were found in the rural area of Lavras, Minas Gerais state, and had spontaneous death. The clinical history included signs of intense dehydration, prostration, dyspnea, lateral decubitus, and extensive lesions in the skin, with a diagnostic suspicion of burn.

Poor body condition, sunked eyes, and extensive areas of alopecia were seen at necropsy of the canids. On the alopecic skin were intensely reddened smooth areas interspersed by thick, irregular, opaque skin with thick, opaque, yellow-brownish crusts (Fig.1) that detached easily. These areas were observed on the head, thorax, limbs and tail, and were more accentuated

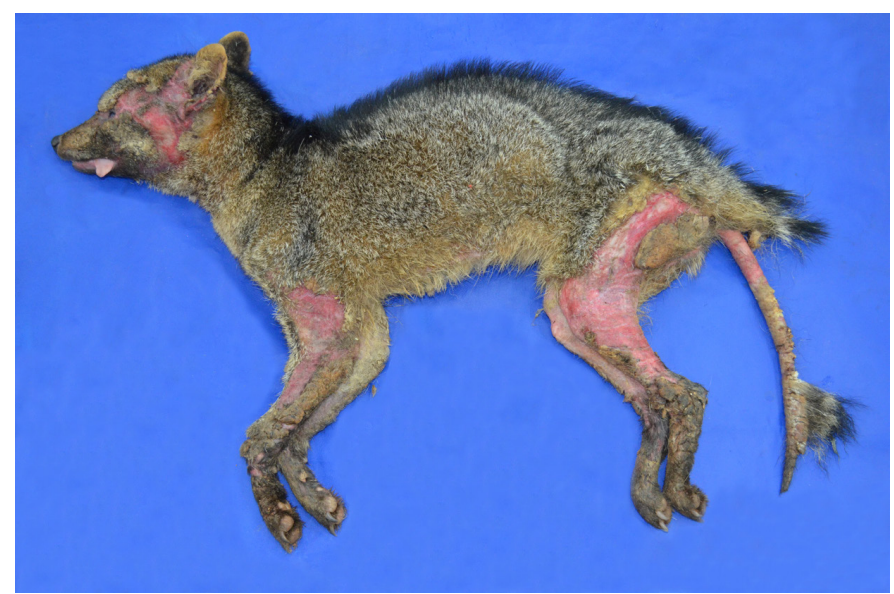

Fig.1. Sarcoptic mange in crab-eating foxes. Gross findings (Ct2): extensive areas of alopecia, intensely erythematous areas, and thick crusts on the head skin, limbs and tail. 


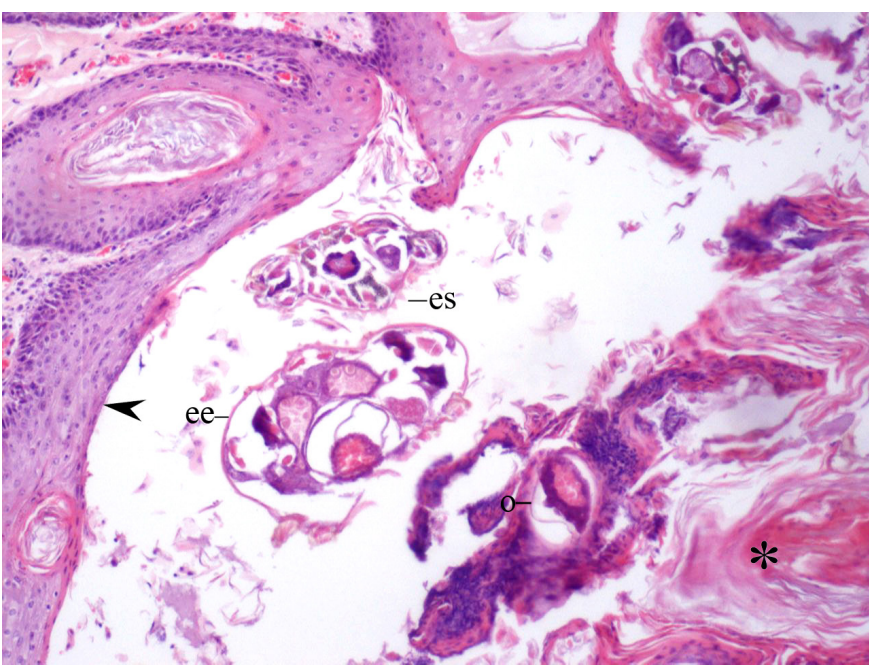

Fig.2. Sarcoptic mange in crab-eating foxes. Histological aspect of the skin (Ct2), with three sections of Sarcoptes scabiei, in which are evidenced rounded idiosoma with thin exoskeleton (ee) and triangular spines on the dorsal surface (es) and mite eggs (o), associated with predominantly orthokeratotic hyperkeratosis (asterisk) and acanthosis (arrow). HE, obj.10x.

on the limbs and tail. Besides the skin lesions were observed pale conjunctival and oral mucosae, signs of dehydration, blood with decreased color and viscosity, moderate enlargement of superficial cervical, axillary, popliteal, mesenteric, superficial inguinal and internal iliac lymph nodes, with edematous and brownish cut surface. In one of the wild canids (Ct2), diffusely reddened kidneys and liver, as well as gastric ulcerations were also observed.

The cytological evaluation of skin and crust samples showed a large number of approximately $0.4 \mathrm{~mm}$-long mites, with globose idiosoma (= mite body) with parallel transverse striae and triangular spines on the dorsal surface, short and broad gnathosoma, and short and thick legs with unsegmented pedicel at the extremities of legs I and II (female specimens), in addition to terminal anus, which are characteristics of Sarcoptes scabiei.

The histologic skin lesions were similar for the two canids, varying only in intensity, being more pronounced in Ct2. Marked acanthosis and hyperkeratosis, predominantly orthokeratotic (Fig.2) were seen, as well as multifocal mild inflammatory infiltrate, predominantly composed of neutrophils and occasional eosinophils, and superficial bacterial colonies. Subcorneal pustules were observed in the skin of one of the canids (Ct2) and there was also a discrete lymphoplasmacytic infiltrate in the superficial dermis. These lesions were associated with large amount of mite sections with short and broad gnathosoma; rounded idiosoma with thin exoskeleton and triangular spines on the dorsal surface; terminal anus; in addition to short and thick legs with mild chitinous coating (Fig. 2 and 3). The mites were seen in tunnels burrowed in the surface epidermis, into and under the stratum corneum. In addition, lung congestion and emphysema (Ct1), and foci of foamy macrophages in alveolar lumen (Ct2); moderate splenic

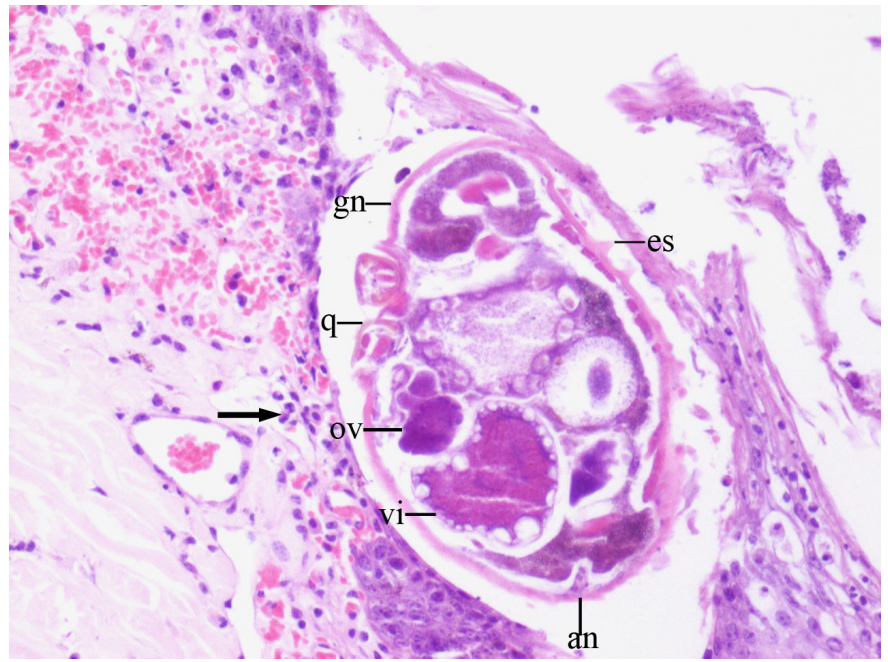

Fig.3. Sarcoptic mange in crab-eating foxes. Histological findings (Ct2). Side view of a female specimen of Sarcoptes scabiei in a tunnel in the superficial epidermis. The mites have a short and broad gnathosoma (gn), globose idiosoma with triangular spines on the dorsal surface (es), terminal anus (an), ovary (ov), and vitelline gland (vi), short and conical legs I and II, with a delicate chitinous coating (q). Lymphoplasmacytic infiltrate (arrow) and haemorrhage in the dermis can also be observed. HE, obj.20x.

hemosiderosis; gastric ulcerations; and marked congestion of the kidneys and liver (Ct2) were observed.

\section{DISCUSSION}

Cerdocyon thous has been studied mainly in endemic areas for leishmaniasis because the species is naturally infected by Leishmania infantum (Cerqueira et al. 2000). With regard to ectoparasites that can infest $C$. thous, parasitism by ticks has already been described in Brazil (Rodrigues \& Daemon 2004), but no description of fatal cases of sarcoptic mange had been reported.

In some wild species, sarcoptic mange can be severe and lead to death. The reasons for this outcome are not fully elucidated, but it may be associated with malnutrition, considering that affected animals spend much less time feeding because of the intense pruritus. Moreover, the severe skin lesions can lead to ulceration, myiasis, bacterial infections, toxemia, and sepsis (Monteiro 2010, Mauldin \& Peters-Kennedy 2016). In cold regions of the Northern Hemisphere, deaths of gray wolves (Canis lupus) with sarcoptic mange have also been attributed to hypothermia related to alopecia due to infestation (Jimenez et al. 2010). In the two crab-eating foxes examined, there were signs of marked dehydration, which were considered important in the progression of the disease to death. There are also reports of cases of sarcoptic mange associated with distemper in red foxes (Little et al. 1998). Distemper lesions were not observed in the animals of this study.

Severe, debilitating and fatal disease, as observed in the crab-eating foxes with $S$. scabiei infestation, has been described in infested red foxes (Vulpes vulpes) (Soulsbury et al. 2007, Nimmervoll et al. 2013), causing a reduction in the population of these animals in several parts of Europe 
(Soulsbury et al. 2007). Bornstein et al. (2001) also described sarcoptic mange in $V$. vulpes, with extensive skin lesions and death. Stone et al. (1974) associated the greater severity of lesions with first exposure to the agent, with death of the red foxes three to four months after the primary exposure. In our cases it was not possible to obtain consistent data on the origin and evolution of the disease.

Poor body condition and extensive cutaneous lesions, with alopecia and intensely reddened areas on the skin, were the most relevant gross findings of the crab-eating foxes. In cases of sarcoptic mange reported in bush dogs (Speothos venaticus) of the state of Mato Grosso, Brazil (Jorge et al. 2008) and in Bolivia (Luque et al. 2014), there is also a description of poor body condition and pronounced hypotrichosis. Pence \& Ueckermann (2002) considered that sarcoptic mange presents a characteristic clinical condition, but varies considerably in severity according to the host species. They also stated that, depending on the host and the response to parasite infestation, it may be accompanied by late hypersensitivity response.

Thick, opaque, yellow-brownish crusts were observed in the skin of the head, thorax, limbs, and tail. Nimmervoll et al. (2013) reported association of crust thickness with the number of mites, that is, the larger the number of mites, the thicker the crusts. Large amount of mites were observed in the skin lesions of the canids. Pence \& Ueckermann (2002) stated that the intensity of these crusted lesions and alopecia varies according to the species and the individual affected, and that thick and dry crusts can crack, leading to hemorrhage or pyoderma, exacerbating skin lesions even more.

The finding of mites with globose body and triangular spines on the dorsal surface, short legs and mouthparts on the cytological examination of skin samples and crusts collected at necropsy confirmed the diagnosis of sarcoptic mange. The differentiation between scabies and mange caused by other mites in animals is mainly based on the peculiar microscopic characteristics of the genus Sarcoptes (Deem et al. 2002, Monteiro 2010). In addition, cytological examination is fast and practical. Other authors have also used cytological exam in the diagnosis of the disease in red foxes (Davidson et al. 2008) and raccoons - Procyon lotor (Rentería-Solís et al. 2014).

The histological analysis of the canids, in addition to mite structures of characteristic morphology, evidenced the skin changes induced by them, such as acanthosis and hyperkeratosis, as well as the tunnels burrowed in the epidermis. Rentería-Solís et al. (2014) also reported marked acanthosis and moderate-to-severe parakeratotic hyperkeratosis, whereas Deem et al. (2002) described orthokeratotic hyperkeratosis. The histological features of epidermal tunnels were also observed in other studies (Deem et al. 2002, Rentería-Solís et al. 2014).

Burn was the initial clinical suspicion, because the canids were free-living animals, coming from areas where fires are frequent in the driest period of the year, when the deaths occurred, as well as by the macroscopic aspect of the skin lesions, with intensely reddened alopecic areas. Burned areas become erythematous and edematous, which are aspects resulting from the vascular response in the dermis. Burn-induced lesions are classified according to their depth (Mauldin \& Peters-Kennedy 2016). The finding of numerous mites in the skin lesions discarded the initial clinical suspicion.
Mixed, multifocal, mild inflammatory infiltrate was observed in the superficial dermis of the crab-eating foxes. Other authors who described scabies, observed an association of the mite infestations with discrete- (Rentería-Solís et al. 2014) to-moderate (Deem et al. 2002, Rentería-Solís et al. 2014) dermatitis, in addition to subcorneal pustules and ulceration of the skin (Rentería-Solís et al. 2014), in Pampas fox Lycalopex gymnocercus, previously Pseudalopex gymnocercus (Deem et al. 2002) and raccoon (Rentería-Solís et al. 2014), although Little et al. (1998) described severe dermatitis in red foxes with scabies.

Assessment of the occurrence of sarcoptic mange in domestic dogs in the region of origin of the crab-eating foxes was not possible, thus correlation of scabies indices between these species could not be analyzed, albeit the probability of transmission between species is considered low (Serra-Freire 2001). Deem et al. (2002) also demonstrated little probability of transmission when analyzing Pampas foxes captured in two different geographic areas; they found a higher rate of infestation with Sarcoptes scabiei in Pampas foxes from the region farthest from the village that had dogs with confirmed sarcoptic mange than in those from areas near the village.

\section{CONCLUSION}

The diagnosis of the two fatal cases of sarcoptic mange in Cerdocyon thous was based on necropsy findings, identification of mites on cytological examination of skin and crust samples, and on histological findings, confirming the importance of these tests. Sarcoptic mange should be considered as a potential cause of disease and death in wild canids.

Acknowledgements.- The authors are grateful to Fundação de Amparo à Pesquisa do Estado de Minas Gerais (FAPEMIG) for supporting the publication of this article.

\section{REFERENCES}

Arlian L.G. 1989. Biology, host relations, and epidemiology of Sarcoptes scabiei. Ann. Rev. Entomol. 34(1):139-161. <http://dx.doi.org/10.1146/ annurev.en.34.010189.001035> <PMid:2494934>

Arlian L.G. \& Vyszenski-Moher D.L. 1988. Lifecycle of Sarcoptes scabiei var. canis. J. Parasitol. 74(3):427-430. <http://dx.doi.org/10.2307/3282050> <PMid:3132547>

Bornstein S., Mörner T. \& Samuel W.M. 2001. Sarcoptes scabiei and sarcoptic mange, p.107-109. In: Samuel W.M., Pybus M.J., Kocan A.A. (Eds), Parasitic Diseases of Wild Mammals. Iowa State University Press, Ames. <http:// dx.doi.org/10.1002/9780470377000.ch5>.

Burkhart C.G., Burkhart C.N. \& Burkhart K.M. 2000. An epidemiologic and therapeutic reassessment of scabies. Cutis 65(4):233-240.<PMid:10795086>

Cerqueira E.J.L., Silva E.M., Monte-Alegre A.F. \& Sherlock I.A. 2000. Considerações sobre pulgas (Siphonaptera) da raposa Cerdocyon thous (Canidae) da área endêmica de leishmaniose visceral de Jacobina, Bahia, Brasil. Revta Soc. Bras. Med. Tropical 33(1):91-93. <http://dx.doi.org/10.1590/S003786822000000100015><PMid:10881126>

Curtis C.F. 2004. Current trends in the treatment of Sarcoptes, Cheyletiella and Otodectes mite infestations in dogs and cats. Vet. Dermatol. 15(2):108-114. <http://dx.doi.org/10.1111/j.1365-3164.2004.00362.x><PMid:15030559>

Davidson R.K., Bornstein S. \& Handeland K. 2008. Long-term study of Sarcoptes scabiei infection in Norwegian red foxes (Vulpes vulpes) indicating host/ parasite adaptation. Vet. Parasitol. 156(3/4):277-283. <http://dx.doi. org/10.1016/j.vetpar.2008.05.019> <PMid:18586406> 
Deem S.L., Noss R.J., Cuellar R.L., Villarroel R., Linn M.J. \& Forrester D.J. 2002. Sarcoptic mange in free-ranging pampas foxes in the Gran Chaco, Bolivia. J. Wildl. Dis. 38(3):625-628. <http://dx.doi.org/10.7589/0090-355838.3.625><PMid:12238385>

Di Bitetti M.S., Di Blanco Y.E., Pereira J.A., Paviolo A. \& Pírez I.J. 2009. Time partitioning favors the coexistence of sympatric crab-eating foxes (Cerdocyon thous) and pampas foxes (Lycalopex gymnocercus). J. Mammal. 90(2):479490. <http://dx.doi.org/10.1644/08-MAMM-A-113.1>

Fain A. 1968. Etude de la variabilité de Sarcoptes scabieis avec une revision des Sarcoptidae. Acta Zool. Pathol. Antverp. 47:1-196.

Faria-Corrêa M., Balbueno R.A., Vieira E.M. \& Freitas T. 2009. Activity, habitat use, density, and reproductive biology of the crab-eating fox (Cerdocyon thous) and comparison with the pampas foxes (Lycalopex gymnocercus) in a Restinga area in the southern Brazilian Atlantic Forest. Mammal. Biol. 74(3):220-229. <http://dx.doi.org/10.1016/j.mambio.2008.12.005>

Jimenez M.D., Bangs E.E., Sime C. \& Asher V.J. 2010. Sarcoptic mange found in wolves in the Rocky Mountains in western United States. J. Wildl. Dis. 46(4):1120-1125. <http://dx.doi.org/10.7589/0090-3558-46.4.1120> $<$ PMid:20966263>

Jorge R.S.P. \& Jorge M.L.S.P. 2014. Carnivora-Canidae (Cachorro-do-mato, Cachorro-vinagre, Lobo-guará e Raposa-do-campo), p.765-774. In: Cubas Z.S., Silva J.C.R. \& Catão-Dias J.L. (Eds), Tratado de Animais Selvagens. $2^{\text {a }}$ ed. Roca, São Paulo.

Jorge R.S.P., Lima E.S. \& Lucarts L.E.B. 2008. Sarna sarcóptica ameaçando cachorros-vinagres (Speothos venaticus) de vida livre em Nova Xavantina, MT. Anais XXXIII Congresso Anual Sociedade de Zoológicos do Brasil Sorocaba, SP. Available at <www.researchgate.net/publication/262216941> Access on Jan. 31, 2017.

Larsson M.H.M.A. 1978. Evidências epidemiológicas da ocorrência de escabiose em humanos causada por Sarcoptes scabiei (Degeer, 1998) var canis (Bourguignon, 1953). Revta Saúde Pública, São Paulo, 12(3):333-339. <http://dx.doi.org/10.1590/S0034-89101978000300007><PMid:108800>

Little S.E., Davidson W.R., Howerth E.W., Rakich P.M. \& Nettles V.F. 1998. Diseases diagnosed in red foxes from southwestern United States. J. Wildl. Dis. 34(3):620-624. <http://dx.doi.org/10.7589/0090-3558-34.3.620> $<$ PMid:9706573>

Luque J.A.D., Muller H., González L. \& Berkunsky I. 2014. Clinical sings suggestive of mange infestation in a free-ranging maned wolf (Chrysocyon brachyurus) in the Moxos Savannahs of Bene, Bolivia. Mastozool. Neotrop. 21(1):135-138

Mauldin E.A. \& Peters-Kennedy J. 2016. Integumentary System. p. 673-674 In: Maxie M.G. (Ed) Jubb, Kennedy and Palmer's Pathology of domestic animals. 6th ed. Elsevier, Edinburgh. <http://dx.doi.org/10.1016/B9780-7020-5317-7.00006-0>.
Monteiro S.G. 2010. Astigmata - Sarnas, p.31-44. In: Ibid. (Ed.), Parasitologia na Medicina Veterinária. Roca, São Paulo.

Nimmervoll H., Hoby S., Robert N., Lommano E., Welle M. \& Ryser-Degiorgis M.-P. 2013. The epizootiology and pathology of sarcoptic mange in coyotes, Canis latrans, from South Texas. J. Wildl. Dis. 49(1):91-102.

Orion E., Marcos B., Davidovici B. \& Wolf R. 2006. Itch and scratch: Scabies and pediculosis. Clin. Dermatol. 24(3):168-175. <http://dx.doi.org/10.1016/j. clindermatol.2005.11.001><PMid:16714197>

Pence D.B. \& Ueckermann E. 2002. Sarcoptic mange in wildlife. Rev. Sci. Tech. Off. Int. Epiz. 21(2):385-398. <http://dx.doi.org/10.20506/rst.21.2.1335> <PMid:11974622>

Pence D.B., Windberg L.A., Pence B.C. \& Sprowls R. 1983. The epizootiology and pathology of sarcoptic mange in coyotes, Canis latrans, from South Texas. J. Parasitol. 69(6):1100-1115. <http://dx.doi.org/10.2307/3280873> <PMid:6425486>

Rentería-Solís Z., Min A.M., Alasaad S., Müller K., Michler F.U., Schmäschke R., Wittstatt U., Rossi L. \& Wibbelt G. 2014. Genetic epidemiology and pathology of raccoon-derived Sarcoptes mites from urban areas of Germany. Med. Vet. Entomol. 28(Suppl.1):98-103. <http://dx.doi.org/10.1111/mve.12079> $<$ PMid:25171612>

Rodrigues A.F.S.F. \& Daemon E. 2004. Ixodídeos e sifonápteros em Cerdocyon thous l. (Carnivora, Canidae) procedentes da zona da mata mineira, Brasil. Arqs Inst. Biológico, São Paulo, 71(3):371-372.

Serra-Freire N.M. 2001. Ácaros (Carrapatos e outros), p.263-315. In: Marcondes C.B. (Ed.), Entomologia Médica e Veterinária. Atheneu, São Paulo.

Soulsbury C.D., Iossa G., Baker P.J., Cole N.C., Funk S.M. \& Harris S. 2007. The impact of sarcoptic mange Sarcoptes scabiei on the British fox Vulpes vulpes population. Mammal. Rev. 37(4):278-296.

Stone W.B., Parks E., Weber B.L. \& Parks F.J. 1974. Experimental transfer of sarcoptic mange from red foxes and wild canids to captive wildlife and domestic animals. N.Y. Fish Game J. 19:1-11.

Sweatman G.K. 1971. Mites and pentastones, p.3-64. In: Davis J.W. \& Anderson R.C. (Eds), Parasitic Diseases of Wild Animals. Iowa State University Press, Ames.

Taylor M.A., Coop R.L. \& Wall R.L. 2010. Diagnóstico laboratorial de parasitismo, p.689-693. In: Ibid. (Ed.), Parasitologia Veterinária. 3a ed. Guanabara Koogan, Rio de Janeiro.

Trovati R.G., Brito B.A. \& Duarte J.M.B. 2007. Área de uso e utilização de habitat de cachorro-do-mato (Cerdocyon thous Linnaeus, 1766) no cerrado da Região Central do Tocantins, Brasil. Mastozool. Neotrop. 14(1):61-68. 